\title{
ANALISIS PERBANDINGAN EFEK GAYA GEMPA PADA DINDING PENAHAN TANAH GRAVITASI DENGAN DINDING PENAHAN TANAH GEOSINTETIK
}

\author{
Indra Jaya Pangestu' ${ }^{1}$ dan Andryan Suhendra ${ }^{2}$ \\ ${ }^{1}$ Program Studi Sarjana Teknik Sipil, Universitas Tarumanagara, Jl. Letjen S. Parman No.1 Jakarta \\ Email: pangestu.indrajaya14@gmail.com \\ ${ }^{2}$ Program Studi Sarjana Teknik Sipil, Universitas Tarumanagara, Jl. Letjen S. Parman No.1 Jakarta \\ Email: andryansuhendra@yahoo.com
}

\begin{abstract}
ABSTRAK
Gempa menjadi salah satu peristiwa alam yang sering terjadi di Indonesia. Gempa dapat memberikan dampak yang destruktif dalam dunia konstruksi khususnya dinding penahan tanah. Dinding penahan tanah harus dibuat kuat terhadap gaya gempa yang terjadi sehingga tidak terjadi keruntuhan. Terdapat berbagai macam tipe dinding penahan tanah yang dapat digunakan. Penulis menganalisis efek gaya gempa terhadap dua tipe dinding penahan tanah yaitu dinding penahan tanah gravitasi dan dinding penahan tanah geosintetik. Penulis menganalisis efek dari gaya gempa terhadap kedua jenis dinding penahan tanah dengan perhitungan manual dan dengan software berbasis metode limit equilibrium atau metode kesetimbangan gaya dengan beberapa perbedaan ketinggian dinding penahan tanah. Pada analisis manual setelah diberikan efek gempa terhadap stabilitas geser, stabilitas guling dan stabilitas daya dukung tanah dihasilkan nilai faktor keamanan dinding penahan tanah geosintetik lebih besar dibandingkan nilai faktor keamanan dinding penahan tanah gravitasi untuk ketiga beda tinggi dinding. Pada analisis menggunakan software metode kesetimbangan gaya setelah diberikan efek gempa, dihasilkan nilai faktor keamanan terhadap stabilitas global dinding penahan tanah geosintetik lebih besar dibandingkan dinding penahan tanah gravitasi untuk ketiga beda tinggi dinding. Sehingga dapat dikatakan dinding penahan tanah geosintetik memiliki ketahanan terhadap efek gempa lebih baik dari dinding penahan tanah gravitasi.
\end{abstract}

Kata kunci: efek gaya gempa, dinding penahan tanah, faktor keamanan, geosintetik

\section{PENDAHULUAN}

\section{Latar belakang}

Gempa memiliki dampak destruktif bagi konstruksi bangunan khususnya dinding penahan tanah. Getaran atau energi yang diberikan oleh gempa berupa getaran dinamis dapat membuat lapisan tanah bergerak sehingga tanah tersebut berubah dari keadaan semula atau mengalami pergerakan. Oleh karena itu perlunya suatu struktur konstruksi pada daerah tersebut untuk direncanakan dan dianalisis berdasarkan gaya gempa yang mungkin akan terjadi di masa yang akan datang.

Penulis mendapatkan sebuah kasus dimana akan dirancangnya dinding penahan tanah di daerah Solok, Sumatera Barat. Dinding penahan tanah yang dianalisis adalah dinding penahan tanah gravitasi dan dinding penahan tanah geosintetik. Dinding penahan tanah yang dianalisis dibedakan menjadi tiga beda tinggi serta tanah timbunan dihitung untuk tanah granular dan tanah non granular.

\section{Batasan masalah}

- $\quad$ Dinding penahan tanah yang dianalisis berupa dinding penahan tanah gravitasi dan dinding penahan tanah geosintetik dengan tinggi 3 meter, 5 meter dan 8 meter.

- $\quad$ Efek muka air tanah tidak diperhitungkan.

- $\quad$ Tanah timbunan dianalisis terhadap dua jenis tanah urug, yaitu tanah granular dan non granular.

- Analisis dinding penahan tanah menggunakan perhitungan manual dan menggunakan software berbasis metode kesetimbangan gaya atau limit equilibrium.

- Parameter data tanah dasar digunakan berdasarkan laporan data tanah yang didapat untuk daerah Solok, Sumatera Barat, tanah timbunan granular dan non granular ditentukan.

- $\quad$ Perbandingan dilakukan berdasarkan nilai faktor keamanan dinding penahan tanah terhadap stabilitas guling, stabilitas geser, stabilitas daya dukung tanah, dan stabilitas global.

\section{Tujuan penelitian}


Tujuan penelitian ini adalah untuk mengetahui efek gaya gempa terhadap dinding penahan tanah gravitasi dan dinding penahan tanah geosintetik serta efek gaya gempa terhadap jenis tanah timbunan.

\section{TINJAUAN PUSTAKA}

\section{Dinding penahan tanah}

Dinding penahan tanah adalah struktur bangunan yang digunakan untuk menahan tanah atau memberikan kestabilan pada tanah untuk mencegah keruntuhan tanah yang miring atau lereng yang kemampuan tidak dapat dijamin oleh tanah itu sendiri. Bangunan dinding penahan tanah digunakan untuk menahan tekanan lateral yang ditimbulkan oleh tanah urug atau tanah asli yang labil.

Dinding penahan tanah memiliki berbagai macam jenis, diantaranya:

Dinding penahan tanah gravitasi (gravity wall)

Merupakan dinding penahan tanah yang bergantung pada massanya sendiri untuk melawan gaya lateral tanah. Dinding penahan tanah jenis ini menggunakan material dari batu atau semen sehingga bisa mempunyai massa yang besar.

Dinding penahan tanah geosintetik (geosynthetic wall)

Pada tipe dinding penahan tanah ini, ada bagian muka dinding terdiri dari tumpukan lembaran geosintetik. Saat konstruksi dinding penahan tanah ini selesai, bagian muka dinding yang terbuka harus di tutup, dikarenakan bahan geosintetik akan terdampak akibat pancaran sinar ultraviolet.

\section{Tekanan tanah lateral}

Tekanan tanah lateral merupakan gaya yang ditimbulkan oleh berat tanah ke arah horizontal maupun vertikal. Pada mulanya, apabila tanah tidak digali, tegangan tanah seimbang ke segala arah. Pada saat melakukan galian, salah satu tegangan lateral akan mengecil terus menerus dan menimbulkan kelebihan tekanan pada satu sisi yang menyebabkan keruntuhan tanah.

Tekanan tanah lateral beban statis dapat dihitung dengan persamaan:

$$
\begin{gathered}
P a=\frac{1}{2} \gamma_{1} H^{2} K a \\
\mathrm{Ka}=\frac{\cos (\alpha-\theta) \sqrt{1+\sin ^{2} \phi_{1}-2 \sin \phi_{1} \cos \Psi_{a}}}{\cos ^{2} \theta\left(\cos \alpha+\sqrt{\sin ^{2} \phi_{1}-\sin ^{2} \alpha}\right)} \\
\Psi_{a}=\sin ^{-1}\left(\frac{\sin \alpha}{\sin \phi_{1}}\right)-\alpha+2 \theta
\end{gathered}
$$

Dengan $\mathrm{Pa}=$ tekanan lateral aktif, $\mathrm{Ka}=$ koefisien tekanan lateral, $\gamma_{1}=$ berat jenis tanah timbunan, $\mathrm{H}=$ ketinggian dinding, $\alpha=$ sudut timbunan, $\phi_{1}=$ sudut geser tanah timbunan, dan $\theta=$ sudut dinding penahan tanah.

Tekanan tanah lateral beban dinamis dapat dihitung dengan persamaan 1 dengan:

$$
\begin{aligned}
& P_{A B}=1 / 2 H^{2}\left(1-k_{V}\right) K_{A E} \\
& \mathrm{~K}_{\mathrm{AE}}=\frac{\cos ^{2}(\phi-\theta-\beta)}{\cos \theta \cos ^{2} \beta \cos (\delta+\beta+\theta)\left[1+\left(\frac{\sin (\delta+\phi) \sin (\phi-\theta-\mathrm{i})}{\cos (\delta+\beta+\theta) \cos (\beta-i)}\right)^{1 / 2}\right]^{2}} \\
& \theta=\tan ^{-1} \frac{k_{h}}{\left(1-k_{h}\right)}
\end{aligned}
$$

Dengan $\mathrm{P}_{\mathrm{AE}}=$ tekanan lateral aktif akibat gempa, $\mathrm{K}_{\mathrm{AE}}=$ koefisien tekanan lateral akibat gempa, $\mathrm{k}_{\mathrm{h}}=0,5$ PGA, dan $\mathrm{k}_{\mathrm{v}}=0$.

\section{Stabilitas dinding penahan tanah}

Besaran tekanan lateral menjadi salah satu faktor utama yang diperhitungkan untuk merencanakan dinding penahan tanah. Tekanan lateral yang terjadi dapat menyebabkan terjadinya geser dan guling. Selain itu hal penting yang harus diperhatikan adalah bentuk struktur dan pelaksanaan konstruksi di lapangan. Oleh karena itu, kestabilan dinding penahan tanah yang harus diperhitungkan antara lain kestabilan tanah terhadap bahaya guling, bahaya geser, serta kapasitas daya dukung. Sehingga konstruksi dinding penahan menjadi aman, dan tidak terjadi keruntuhan. 


\section{Stabilitas guling}

Berdasarkan SNI 8460:2017, angka faktor keamanan guling minimum yang disyaratkan sebesar 2. Angka faktor keamanan (Fk) terhadap guling dapat diperoleh dari persamaan:

$$
F k=\frac{\sum M R}{\sum M o}
$$

dengan $\Sigma \mathrm{M}_{\mathrm{R}}=$ jumlah momen penahan guling, $\Sigma \mathrm{M}_{\mathrm{O}}=$ jumlah momen guling pada dinding penahan tanah.

\section{Stabilitas geser}

Berdasarkan SNI 8460:2017, angka faktor keamanan geser minimum yang disyaratkan sebesar 1,5. Angka faktor keamanan (Fk) terhadap geser dapat diperoleh dari persamaan:

$$
F k=\frac{\left(\sum V\right) \tan \delta+B \times C a}{\sum H}
$$

dengan ca $=$ adhesi antara dasar dinding dan tanah, $\Sigma \mathrm{H}=$ gaya horizontal pada dinding, $\Sigma \mathrm{V}=$ jumlah gaya vertikal pada dinding, $\mathrm{B}=$ lebar telapak dinding penahan tanah, $\delta=$ friksi antara dinding dan tanah

\section{Pengecekan eksentrisitas}

Eksentrisitas yang terjadi pada struktur dinding penahan tanah dapat diperoleh dari persamaan:

$$
e=\frac{B}{4}-\frac{\sum M}{\sum V}
$$

Dengan $\Sigma \mathrm{M}=$ jumlah momen yang bekerja pada dinding dan $\Sigma \mathrm{V}$ adalah jumlah gaya vertikal pada dinding

\section{Daya Dukung Tanah}

Tekanan maksimum yang bekerja pada dasar pondasi dapat diperoleh dari persamaan:

Dengan Pmax = tekanan maksimum pada dasar $P \max =\frac{\sum_{V}}{B}\left(1+\frac{6 e}{B}\right)$ pondasi, e $=$ eksentrisitas

Pmax tidak boleh melebihi tekanan tanah yang diijinkan dari kapasitas daya dukung pondasi. Daya dukung ultimit (qu) pada pondasi jalur dapat dihitung dengan persamaan:

$$
\mathrm{qu}=\mathrm{c}_{\mathrm{f}} \mathrm{N}_{\mathrm{c}} \mathrm{d}_{\mathrm{c}} \mathrm{i}_{\mathrm{c}}+\mathrm{qN}_{\mathrm{q}} \mathrm{d}_{\mathrm{q}} \mathrm{i}_{\mathrm{q}}+0.5 \gamma_{\mathrm{f}} \mathrm{B}^{\prime} \mathrm{N}_{\gamma} \mathrm{d}_{\gamma} \mathrm{i}_{\gamma}
$$

Dengan $\mathrm{c}_{\mathrm{f}}=$ kohesi pada tanah pondasi, $\gamma_{\mathrm{f}}=$ berat volume tanah pondasi, $\phi_{\mathrm{f}}=$ kuat geser tanah pondasi, Df $=$ kedalaman dinding yang tertanam, $\mathrm{N}=$ faktor daya dukung, $\mathrm{d}=$ faktor kedalaman.

Dengan diambil syarat faktor keamanan sebagai berikut:

1. Stabilitas geser, FK $>2$

2. Stabilitas guling FK $>1,5$

3. Stabilitas daya dukung tanah FK $>3$

4. Stabilitas global FK $>1,5$

5. Stabilitas terhadap gempa FK $>1,1$

\section{METODOLOGI PENELITIAN}

Dalam penulisan ini dilakukan beberapa tahapan yang dapat diuraikan sebagai berikut:

Tahapan pertama adalah pengambilan data proyek daerah Solok, Sumatera Barat.

Tahapan kedua adalah pengolahan data tanah untuk parameter tanah dasar.

Tahapan ketiga adalah analisis stabilitas dinding penahan tanah terhadap beban statis.

Tahapan keempat adalah analisis stabilitas dinding penahan tanah terhadap beban gempa.

Tahapan kelima adalah analisis perbandingan antara hasil perhitungan stabilitas dinding penahan tanah gravitasi dengan dinding penahan tanah geosintetik untuk beban statis dan beban gempa

Tahapan keenam adalah menarik kesimpulan berdasarkan hasil perbandingan pada tahap kelima untuk mengetahui efek gaya gempa terhadap dinding penahan tanah gravitasi dan dinding penahan tanah geosintetik. 


\section{ANALISIS DAN PEMBAHASAN}

Data tanah yang digunakan didapat dari hasil tes tanah yang dilakukan oleh suatu perusahaan konstruksi, terdiri dari 5 data borlog dan 6 data sondir dari proyek yang berlokasi di Solok, Sumatera Barat. Data tanah sondir dan borlog yang ada di rata-rata sehingga menghasilkan 1 (satu) data berupa sondir dan borlog, lalu digunakan korelasi data tanah sondir dan borlog ke parameter tanah yang dibutuhkan dan disajikan dalam tabel 1.

Tabel 1 Data tanah rata-rata penentuan parameter tanah dasar

\begin{tabular}{|c|c|c|c|c|c|c|c|c|}
\hline Kedalaman & $\begin{array}{c}\mathrm{qc} \\
(\mathrm{kg} / \mathrm{cm} 2)\end{array}$ & $\begin{array}{c}\mathrm{tf} \\
(\mathrm{kg} / \mathrm{cm})\end{array}$ & N-SPT & $\begin{array}{c}\text { N-SPT } \\
\text { Rata }\end{array}$ & $\begin{array}{c}\text { Tipe } \\
\text { Tanah }\end{array}$ & $\gamma$ & $\phi$ & $\mathrm{C}_{2}$ \\
\hline 1 & 11,33 & 20 & 10,4 & \multirow{5}{*}{19,68} & \multirow{5}{*}{ CL } & \multirow{5}{*}{18} & \multirow{5}{*}{25} & \multirow{5}{*}{20} \\
\hline 2 & 18,33 & 40 & 24 & & & & & \\
\hline 3 & 16 & 60 & 22,8 & & & & & \\
\hline 4 & 14,67 & 80 & 21,8 & & & & & \\
\hline 5 & 17,33 & 100 & 19,4 & & & & & \\
\hline 6 & 27,33 & 120 & 16,6 & & & & & \\
\hline 7 & 77,17 & 149 & 13,8 & & & & & \\
\hline
\end{tabular}

Sedangkan untuk parameter tanah timbunan yang digunakan disajikan dalam tabel 2.

Tabel 2. Parameter tanah timbunan

\begin{tabular}{|c|c|c|c|c|}
\hline No & Jenis Tanah & \multicolumn{3}{|c|}{ Parameter Tanah } \\
\hline \multirow{3}{*}{1} & \multirow{3}{*}{ Tanah Granular } & $\gamma$ & 19 & $\mathrm{kN} / \mathrm{m}^{3}$ \\
\hline & & C & 0 & $\mathrm{kN} / \mathrm{m}^{2}$ \\
\hline & & $\phi$ & 35 & kerajat \\
\hline \multirow{3}{*}{2} & \multirow{3}{*}{$\begin{array}{c}\text { Tanah Non } \\
\text { Granular }\end{array}$} & $\gamma$ & 17 & $\mathrm{kN} / \mathrm{m}^{3}$ \\
\hline & & C & 25 & $\mathrm{kN} / \mathrm{m}^{2}$ \\
\hline & & $\phi$ & 20 & Derajat \\
\hline
\end{tabular}

Parameter dinding penahan tanah gravitasi disajikan dalam tabel 3, dan parameter dinding penahan tanah geosintetik yang digunakan disajikan dalam tabel 4

Tabel 3. Parameter dinding penahan tanah gravitasi

\begin{tabular}{|c|c|c|c|c|}
\hline No & Tipe Dinding & \multicolumn{3}{|c|}{ Dimensi } \\
\hline \multirow{6}{*}{1} & \multirow{6}{*}{$\begin{array}{c}\text { Gravity Wall } 1 \text { (GW } \\
1)\end{array}$} & $\mathrm{H}$ & 3 & $\mathrm{~m}$ \\
\hline & & $\mathrm{D}$ & 1 & $\mathrm{~m}$ \\
\hline & & B1 & 0,3 & $\mathrm{~m}$ \\
\hline & & B2 & 1,5 & $\mathrm{~m}$ \\
\hline & & $\mathrm{D}$ & 0,4 & $\mathrm{~m}$ \\
\hline & & B & 0,4 & $\mathrm{~m}$ \\
\hline \multirow{6}{*}{2} & \multirow{6}{*}{$\begin{array}{c}\text { Gravity Wall } 2 \text { (GW } \\
\text { 2) }\end{array}$} & $\mathrm{H}$ & 5 & $\mathrm{~m}$ \\
\hline & & $\mathrm{D}$ & 1 & $\mathrm{~m}$ \\
\hline & & B1 & 0,3 & $\mathrm{~m}$ \\
\hline & & B2 & 2,5 & $\mathrm{~m}$ \\
\hline & & $\mathrm{D}$ & 0,6 & $\mathrm{~m}$ \\
\hline & & $\mathrm{B}$ & 0,6 & $\mathrm{~m}$ \\
\hline 3 & Gravity Wall 3 (GW & $\mathrm{H}$ & 8 & $\mathrm{~m}$ \\
\hline
\end{tabular}


3)

\begin{tabular}{ccc}
$\mathrm{D}$ & 1 & $\mathrm{~m}$ \\
\hline $\mathrm{B} 1$ & 0,3 & $\mathrm{~m}$ \\
\hline $\mathrm{B} 2$ & 5 & $\mathrm{~m}$ \\
\hline $\mathrm{D}$ & 1 & $\mathrm{~m}$ \\
\hline $\mathrm{B}$ & 1 & $\mathrm{~m}$
\end{tabular}

Tabel 4 Parameter dinding penahan tanah geosintetik

\begin{tabular}{|c|c|c|c|c|}
\hline No & Tipe Dinding & \multicolumn{3}{|c|}{ Dimensi } \\
\hline \multirow{4}{*}{1} & \multirow{4}{*}{ Geosintetik 1 (GE 1) } & $\mathrm{H}$ & 3 & $\mathrm{~m}$ \\
\hline & & $\mathrm{D}$ & 1 & $\mathrm{~m}$ \\
\hline & & FK & 2 & \\
\hline & & $\Psi$ & 0 & derajat \\
\hline \multirow{4}{*}{2} & \multirow{4}{*}{ Geosintetik 2 (GE 2) } & $\mathrm{H}$ & 5 & $\mathrm{~m}$ \\
\hline & & $\mathrm{D}$ & 1 & $\mathrm{~m}$ \\
\hline & & FK & 2 & \\
\hline & & $\Psi$ & 0 & derajat \\
\hline \multirow{4}{*}{3} & \multirow{4}{*}{ Geosintetik 3 (GE 3) } & $\mathrm{H}$ & 8 & $\mathrm{~m}$ \\
\hline & & $\mathrm{D}$ & 1 & $\mathrm{~m}$ \\
\hline & & FK & 2 & \\
\hline & & $\Psi$ & 0 & derajat \\
\hline
\end{tabular}

Parameter yang ada digunakan untuk analisis sehingga menghasilkan nilai faktor keamanan untuk stabilitas geser, stabilitas guling, stabilitas daya dukung tanah dan stabilitas global baik untuk beban statis ataupun beban gempa.

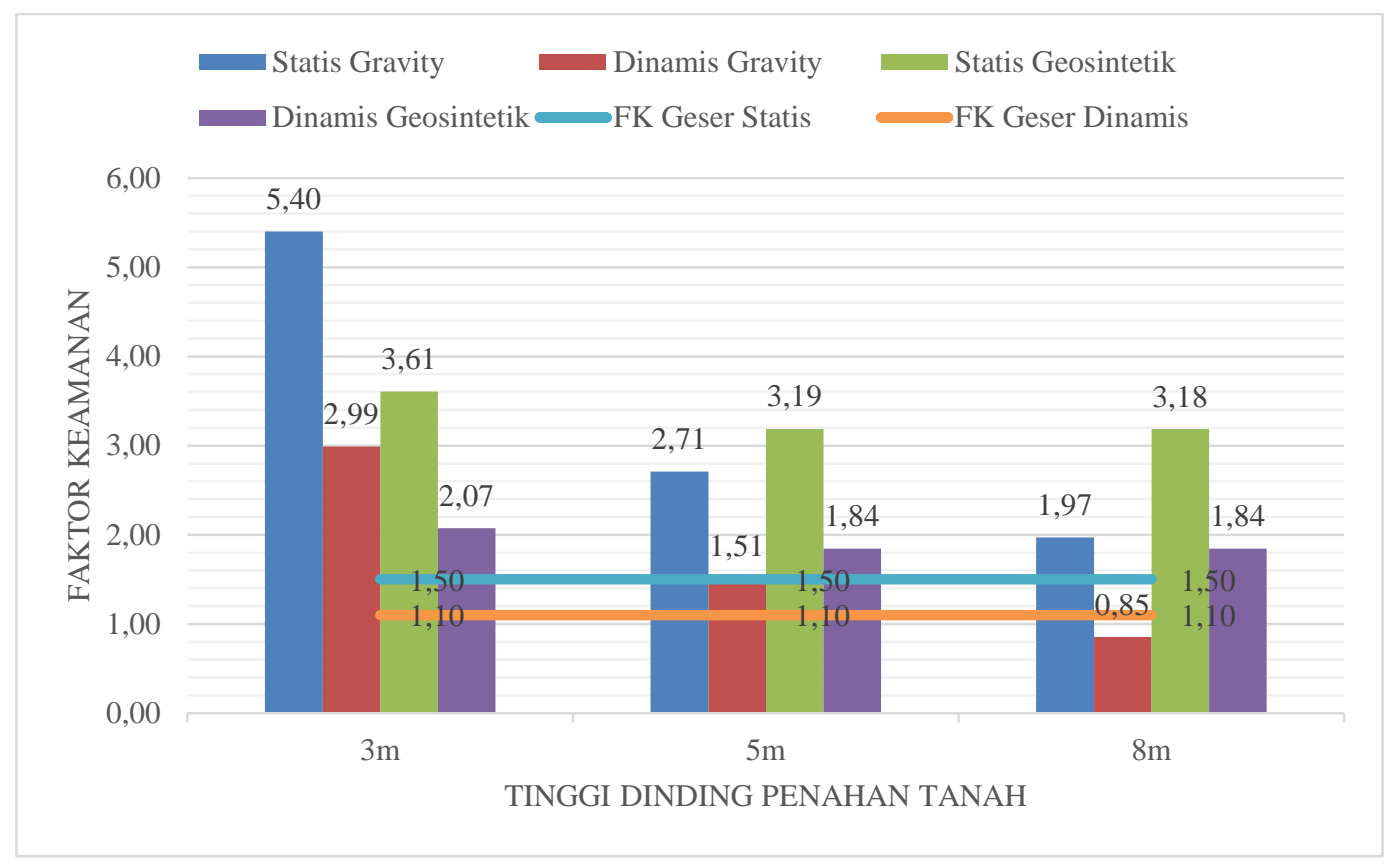

Gambar 1. Grafik hasil perhitungan nilai faktor keamanan dinding penahan tanah terhadap stabilitas geser 
Analisis Perbandingan Efek Gaya Gempa Pada Dinding

Penahan Tanah Gravitasi dengan Dinding Penahan Tanah

Geosintetik

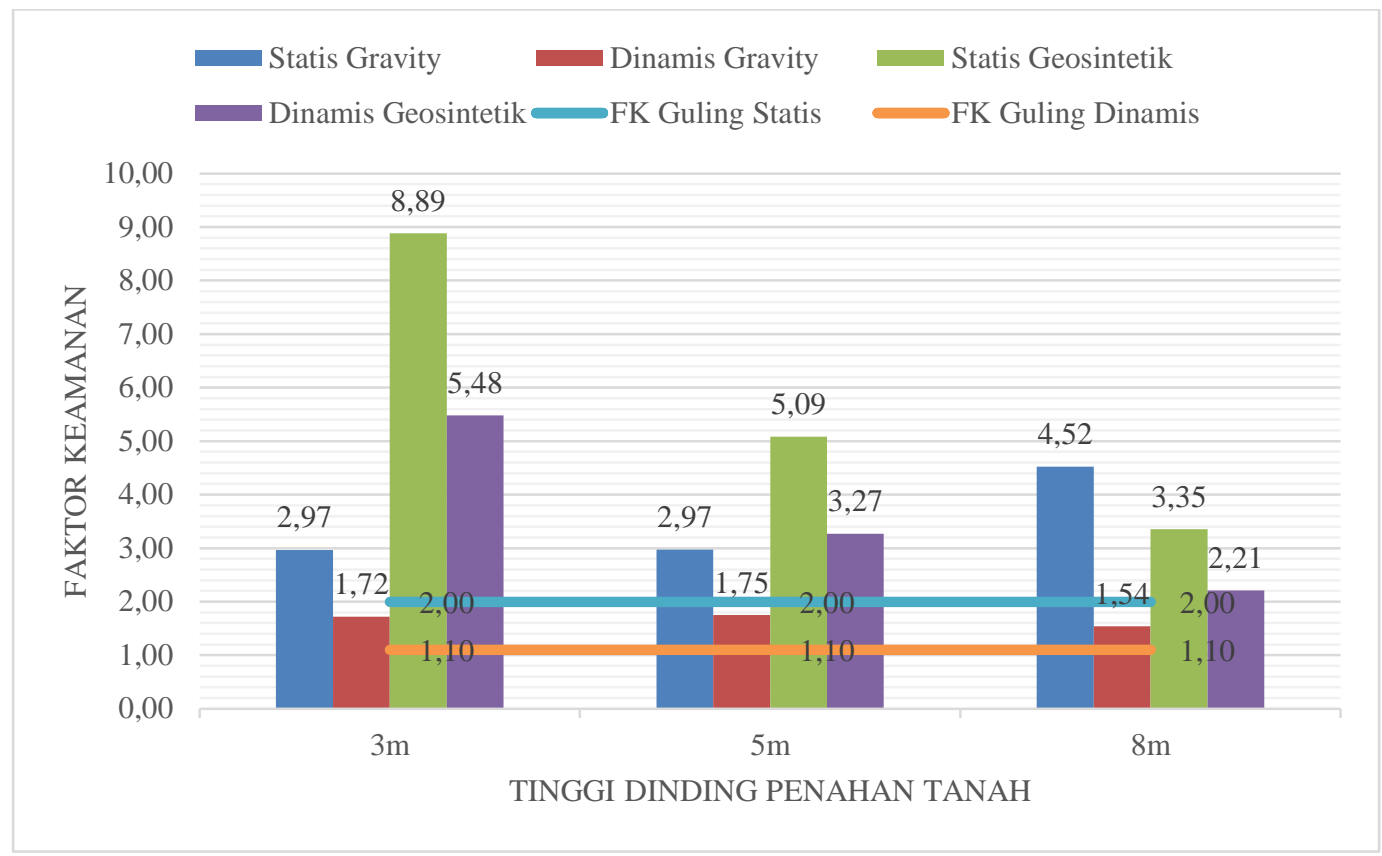

Gambar 2. Grafik hasil perhitungan nilai faktor keamanan dinding penahan tanah terhadap stabilitas guling

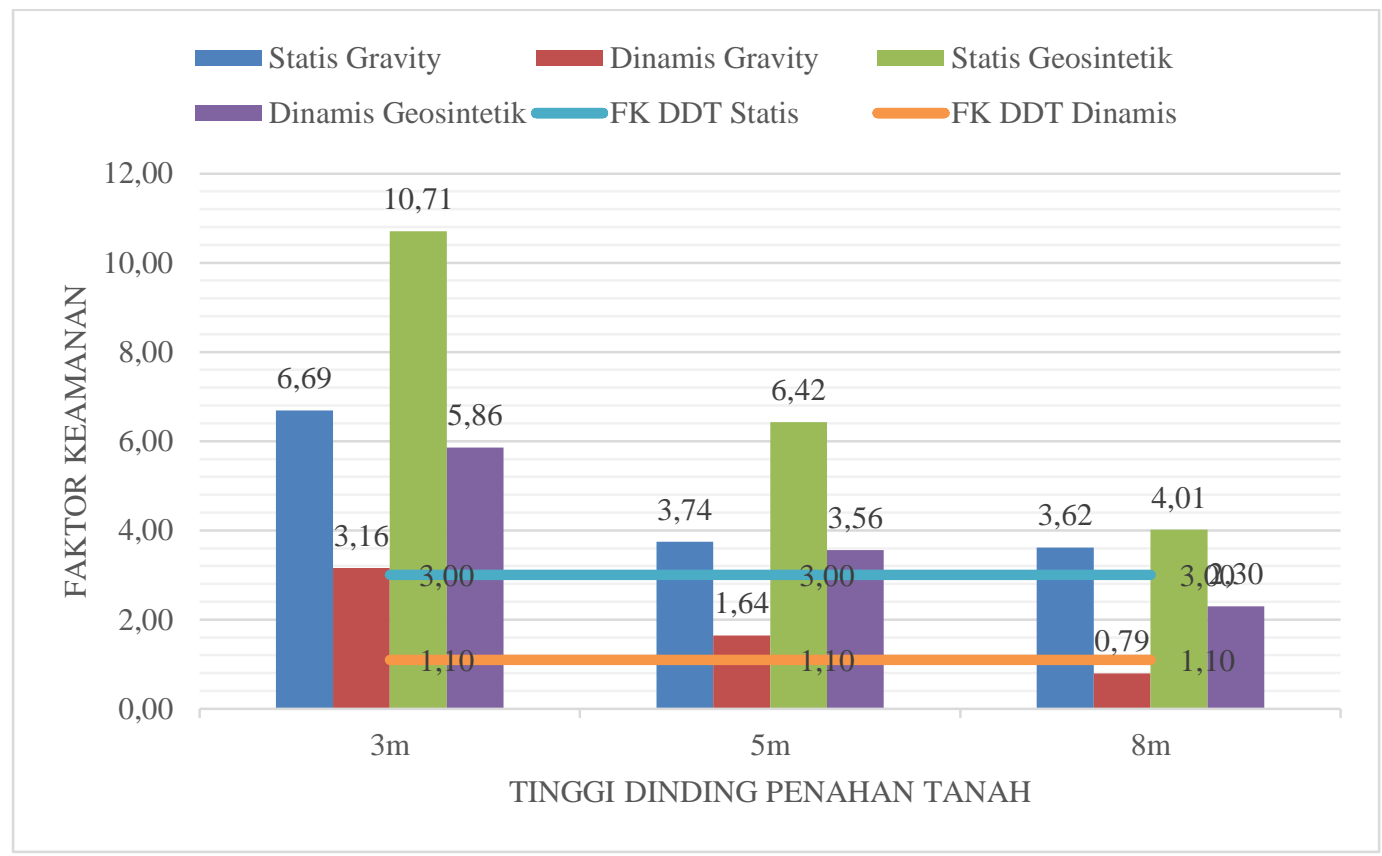

Gambar 3. Grafik hasil perhitungan nilai faktor keamanan dinding penahan tanah terhadap stabilitas daya dukung tanah 


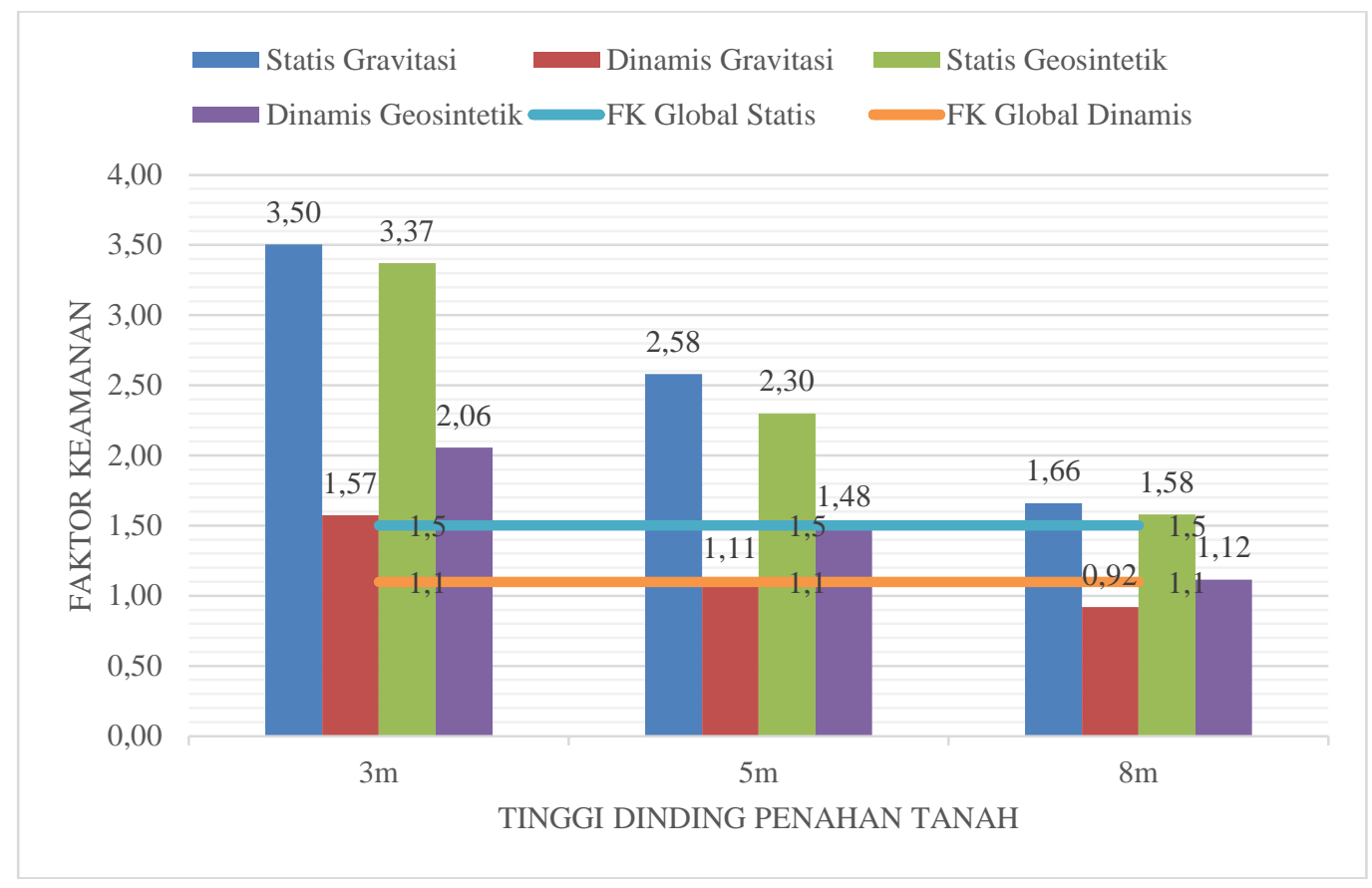

Gambar 4. Grafik hasil perhitungan nilai faktor keamanan dinding penahan tanah terhadap stabilitas global untuk tanah granular

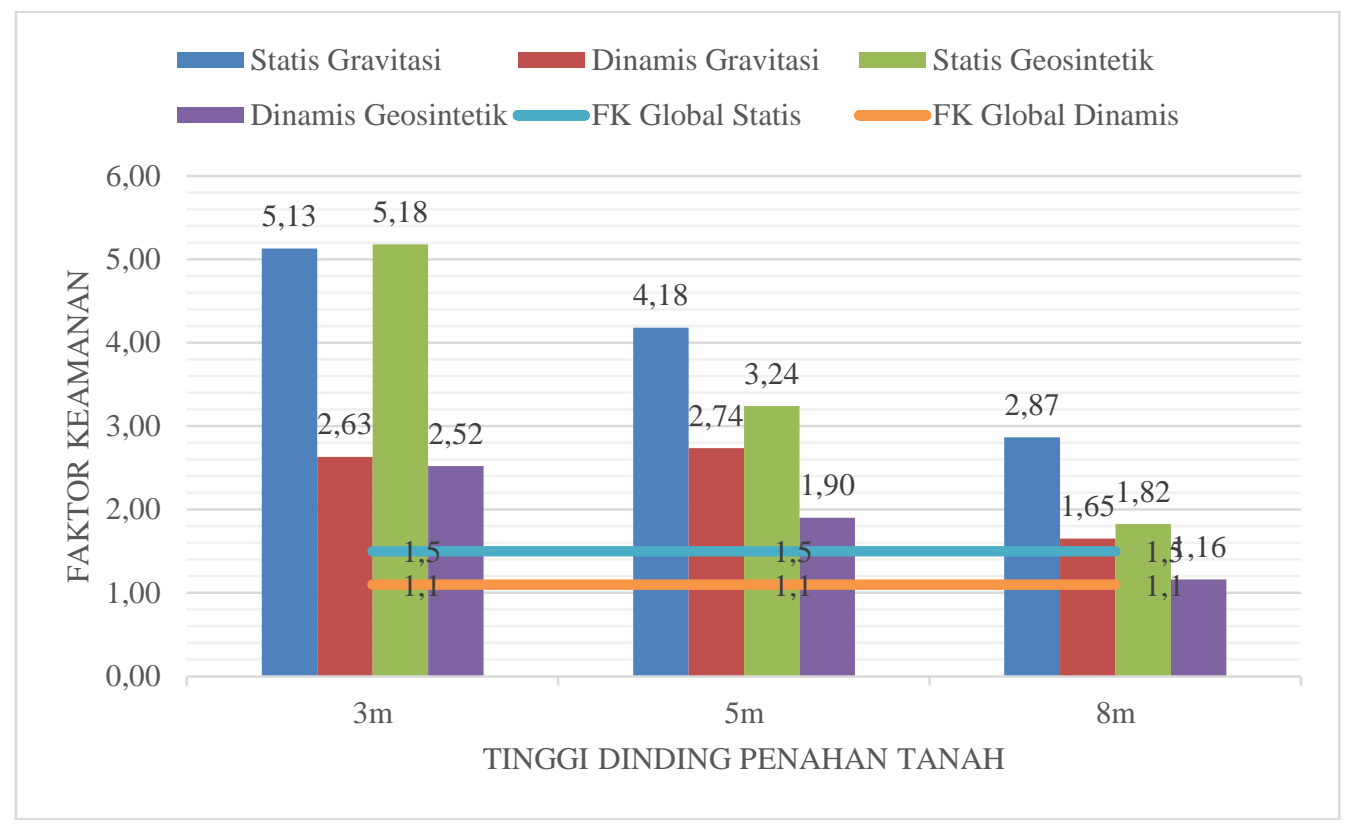

Gambar 4. Grafik hasil perhitungan nilai faktor keamanan dinding penahan tanah terhadap stabilitas global untuk tanah non granular

Pada gambar 1 menunjukkan besaran nilai faktor keamanan dinding penahan tanah terhadap stabilitas geser untuk kedua jenis dinding penahan tanah. Dapat dilihat dinding penahan tanah gravitasi menghasilkan nilai faktor keamanan dalam kondisi statis dan dinamis yang lebih besar dibandingkan dinding penahan tanah geosintetik pada tinggi dinding 3 meter. Sedangkan pada tinggi dinding 5 meter dan 8 meter, nilai faktor keamanan statis dan dinamis yang dihasilkan dinding penahan tanah geosintetik lebih besar dibandingkan dinding penahan tanah gravitasi. Terhadap pengaruh dengan gempa, dinding penahan tanah gravitasi dengan tinggi dinding 5 meter dan 8 meter menghasilkan nilai faktor keamanan dibawah syarat batas faktor kemananan gempa, sedangkan untuk dinding penahan tanah geosintetik untuk ketiga beda tinggi masih menghasilkan nilai faktor keamanan diatas syarat batas. 
Pada gambar 2 menunjukkan menunjukkan besaran nilai faktor keamanan dinding penahan tanah terhadap stabilitas guling untuk kedua jenis dinding penahan tanah. Dapat dilihat dinding penahan tanah geosintetik menghasilkan nilai faktor keamanan dalam kondisi statis dan dinamis yang lebih besar dibandingkan dinding penahan tanah gravitasi pada ketiga beda tinggi dinding. Terhadap pengaruh dengan gempa, baik dinding penahan tanah gravitasi maupun dinding penahan tanah geosintetik menghasilkan nilai faktor keamanan diatas syarat batas, dengan nilai faktor keamanan dinamis dinding penahan tanah geosintetik lebih besar dibandingkan dinding penahan tanah gravitasi untuk ketiga beda tinggi.

Pada gambar 3 menunjukkan besaran nilai faktor keamanan dinding penahan tanah terhadap stabilitas daya dukung tanah untuk kedua jenis dinding penahan tanah. Dapat dilihat dinding penahan tanah geosintetik menghasilkan nilai faktor keamanan dalam kondisi statis dan dinamis yang lebih besar dibandingkan dinding penahan tanah gravitasi pada ketiga beda tinggi dinding. Terhadap pengaruh dengan gempa, dinding penahan tanah gravitasi dengan tinggi 3 meter dan 5 meter masih menghasilkan nilai faktor keamanan diatas syarat batas sedangkan tinggi 8 meter menghasilkan nilai dibawah syarat batas faktor keamanan, untuk dinding penahan tanah geosintetik menghasilkan nilai faktor keamanan diatas syarat batas faktor keamanan untuk ketiga beda tinggi.

Pada gambar 4 menunjukkan besaran nilai faktor keamanan dinding penahan tanah terhadap stabilitas global untuk kedua jenis dinding penahan tanah. Dapat dilihat semua dinding penahan tanah memenuhi syarat batas faktor keamanannya baik statis maupun dinamis kecuali nilai faktor keamanan dinamis untuk dinding penahan tanah gravitasi dengan tinggi 8 meter. Perubahan yang terjadi dari nilai faktor keamanan statis ke dinamis pada dinding penahan tanah gravitasi lebih besar dibandingkan dinding penahan tanah geosintetik. Nilai faktor keamanan terhadap stabilitas global dengan beban dinamis dinding penahan tanah geosintetik lebih besar dibandingkan nilai faktor keamanan dinding penahan tanah gravitasi untuk ketiga beda tinggi.

Pada gambar 5 menunjukkan besaran nilai faktor keamanan dinding penahan tanah terhadap stabilitas global untuk kedua jenis dinding penahan tanah. Dapat dilihat semua dinding penahan tanah memenuhi syarat batas faktor keamanannya baik statis maupun dinamis. Nilai faktor keamanan terhadap stabilitas global dengan beban dinamis dinding penahan tanah geosintetik lebih kecil dibandingkan nilai faktor keamanan dinding penahan tanah gravitasi untuk ketiga beda tinggi.

\section{KESIMPULAN}

Dari analisa perbandingan nilai faktor keamanan dinding penahan tanah terhadap stabilitasnya menghasilkan kesimpulan sebagai berikut:

1. Terhadap stabilitas geser, dinding penahan tanah gravitasi menghasilkan nilai faktor kemanan dalam kondisi statis dan dinamis yang lebih besar dibandingkan dinding penahan tanah geosintetik pada tinggi dinding 3 meter. Sedangkan pada tinggi dinding 5 meter dan 8 meter, nilai faktor keamanan statis dan dinamis yang dihasilkan dinding penahan tanah geosintetik lebih besar dibandingkan dinding penahan tanah gravitasi. Terhadap pengaruh dengan gempa, dinding penahan tanah gravitasi dengan tinggi dinding 5 meter dan 8 meter menghasilkan nilai faktor keamanan dibawah syarat batas faktor kemananan gempa, sedangkan untuk dinding penahan tanah geosintetik untuk ketiga beda tinggi masih menghasilkan nilai faktor keamanan diatas syarat batas.

2. Terhadap stabilitas guling, dinding penahan tanah geosintetik menghasilkan nilai faktor kemanan dalam kondisi statis dan dinamis yang lebih besar dibandingkan dinding penahan tanah gravitasi pada ketiga beda tinggi dinding. Terhadap pengaruh dengan gempa, baik dinding penahan tanah gravitasi maupun dinding penahan tanah geosintetik menghasilkan nilai faktor keamanan diatas syarat batas, dengan nilai faktor keamanan dinamis dinding penahan tanah geosintetik lebih besar dibandingkan dinding penahan tanah gravitasi untuk ketiga beda tinggi.

3. Terhadap stabilitas daya dukung tanah, dinding penahan tanah geosintetik menghasilkan nilai faktor kemanan dalam kondisi statis dan dinamis yang lebih besar dibandingkan dinding penahan tanah gravitasi pada ketiga beda tinggi dinding. Terhadap pengaruh dengan gempa, dinding penahan tanah gravitasi dengan tinggi 3 meter dan 5 meter masih menghasilkan nilai faktor keamanan diatas syarat batas sedangkan tinggi 8 meter menghasilkan nilai dibawah syarat batas faktor keamanan, untuk dinding penahan tanah geosintetik menghasilkan nilai faktor keamanan diatas syarat batas faktor keamanan untuk ketiga beda tinggi.

4. Terhadap stabilitas global melalui pengujian software untuk tanah urug granular, semua dinding penahan tanah memenuhi syarat batas faktor keamanannya baik statis maupun dinamis kecuali nilai faktor keamanan dinamis untuk dinding penahan tanah gravitasi dengan tinggi 8 meter. Perubahan yang terjadi dari nilai faktor keamanan statis ke dinamis pada dinding penahan tanah gravitasi lebih besar dibandingkan dinding penahan tanah geosintetik. Nilai faktor keamanan terhadap stabilitas global dengan beban dinamis dinding penahan tanah geosintetik lebih besar dibandingkan nilai faktor keamanan dinding penahan tanah gravitasi untuk ketiga beda tinggi. 
5. Terhadap stabilitas global melalui pengujian software untuk tanah urug non-granular Semua dinding penahan tanah memenuhi syarat batas faktor keamanannya baik statis maupun dinamis. Nilai faktor keamanan terhadap stabilitas global dengan beban dinamis dinding penahan tanah geosintetik lebih kecil dibandingkan nilai faktor keamanan dinding penahan tanah gravitasi untuk ketiga beda tinggi.

6. Dari hasil yang didapat, terhadap stabilitas geser, stabilitas guling, stabilitas daya dukung tanah serta stabilitas global, dinding penahan tanah geosintetik memiliki ketahanan yang lebih baik dibandingkan dinding penahan tanah gravitasi.

\section{DAFTAR PUSTAKA}

Das, B. M. 2011. Principles of Foundation Engineering Seventh Edition. Cengage Learning, United States of America.

Kramer, Steven L. 1996. Geotechnical Earthquake Engineering. Prentice Hall, United States of America. Badan Standarisasi Nasional. 2017. SNI 8460:2017 Persyaratan Perancangan Geoteknik. BSN, Jakarta. 
